\title{
GRK5 wt Allele
}

National Cancer Institute

\section{Source}

National Cancer Institute. GRK5 wt Allele. NCI Thesaurus. Code C51203.

Human GRK5 wild-type allele is located within 10q24-qter and is approximately $248 \mathrm{~kb}$ in length. This allele, which encodes $\mathrm{G}$ protein-coupled receptor kinase 5 protein, plays a role in the deactivation of $\mathrm{G}$ protein-coupled receptors and is involved in the regulation of cyclic AMP concentrations. 